\title{
Creutzfeldt-Jakob Disease in the Light of Diffusion Magnetic Resonance Imaging Findings
}

\author{
Difüzyon Manyetik Rezonans Görüntüleme Bulguları Işı̆̆ında \\ Creutzfeldt-Jakob Hastalı̆̆1
}

Nesrin Helvacı Yılmaz¹, Fikret Aysal1 ${ }^{1}$ Özdil Başkan², Ebru Erbayat Altay¹, Ahmet Mithat Tavlı1, Didem Taşkın 1 , Lütfü Hanoğlu ${ }^{1}$

${ }^{1}$ Medipol University, Faculty of Medicine, Department of Neurology, İstanbul, Turkey 2Medipol University Faculty of Medicine, Department of Radiology, İstanbul, Turkey

Key Words: Creutzfeldt-Jakob disease, cortical ribboning

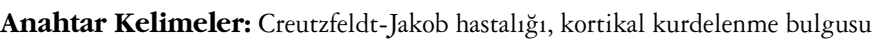

Conflicts of Interest: The authors reported no conflict of interest related to this article.

Çıkar Çatışması: Yazarlar bu makale ile ilgili olarak herhangi bir çıkar çatışması bildirmemiştir.

\section{Case}

Fifty-seven year old male patient came to us with forgetfulness, sleepiness, hand tremor, sluggish movements and withdrawn mood. The patient's place, time and people orientation was disrupted in his neurological examination. There was postural tremor in the bilateral upper extremities. There was no pathological reflex. Routine biochemistry, hemogram, sedimentation, vitamin B12, thyroid function tests, cranial magnetic resonance imaging (MRI) and electroencephalography (EEG) were assessed as normal. He scored 13/30 points in Mini-mental state evaluation. While the second cranial MRI at the $45^{\text {th }}$ day was normal, the diffusion restrictions in the frontal pole, anterior interhemispheric fissure and bilateral insular cortex seen in the diffusion-weighted imaging (DWI) attracted attention (Figures 1,2). There was a widespread sluggishness in the EEG. Infection, autoimmune and paraneoplastic markers in the peripheral blood and cerebrospinal fluid (CSF) to investigate sub-acute onset dementia etiology were all negative. In terms of CSF, there were no cells, the biochemistry tests were normal, 14-3-3 protein was positive, tau protein and neuron-specific enolase values were normal. Neuropsychometric

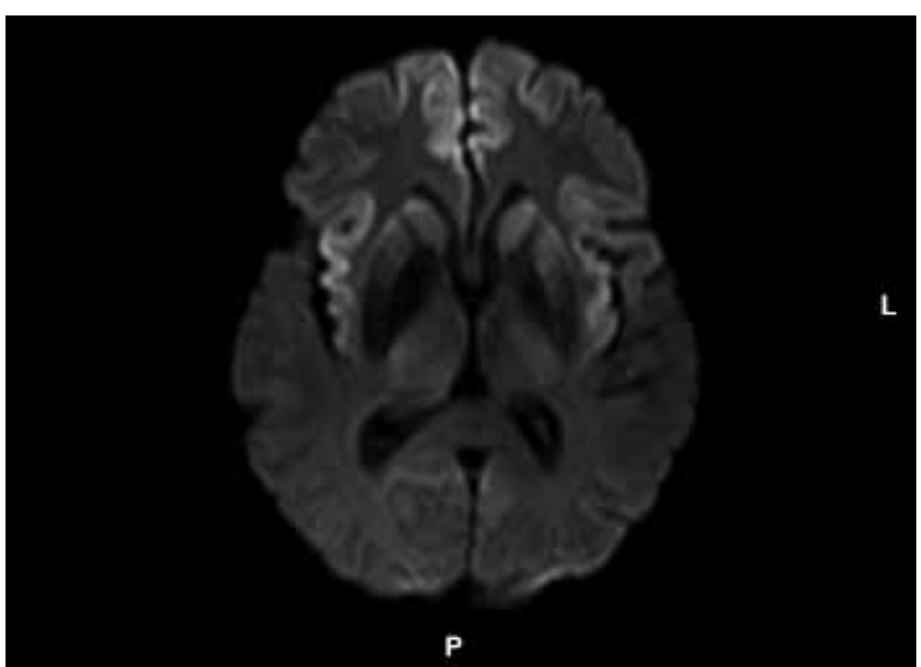

Figure 1. Diffusion-weighted image of ribbon sign in bilateral frontal and insular cortices 


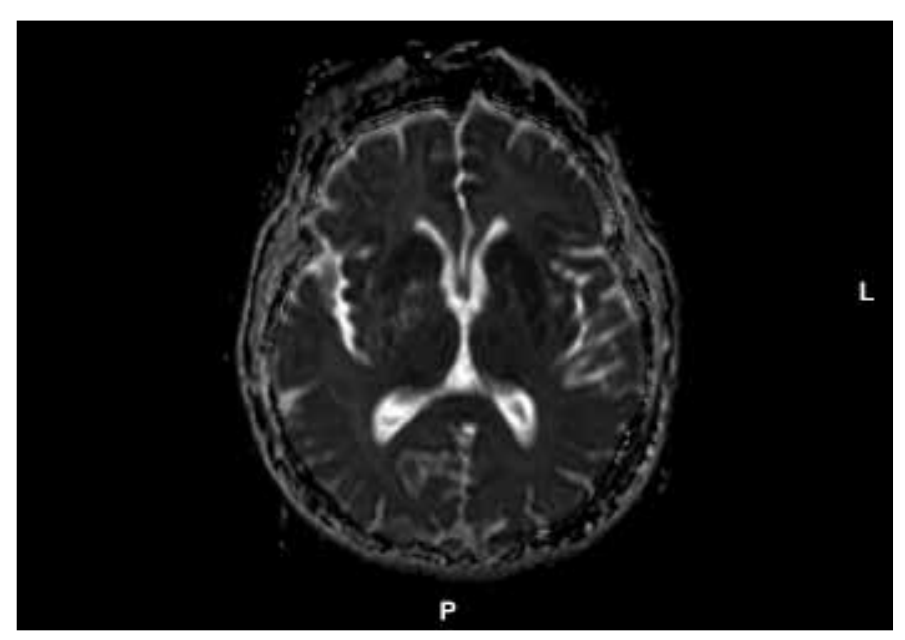

Figure 2. Apparent diffusion coefficient (ADC) image of ribbon sign in bilateral frontal and insular cortices

evaluation was compatible with frontal dysfunction that is characterized by global cognitive impairment. The patient was followed with Creutzfeldt-Jacob disease (CJD) diagnosis.

Imaging plays an important role in the diagnosis of dementia and in ruling out other conditions during the differential diagnosis. It was shown that the increased signal intensity seen in DWI has 92\% sensitivity (1) for sporadic CJD. Increased signal strength in bilateral caudate and putamen in conventional diffusion- weighted MRI is seen in $80 \%$ of the patients (2). Recent studies also emphasized the importance of the cortical ribbon sign in the diagnosis (1). For the diagnosis of sporadic CJD, DWI must satisfy one of the criteria below (3):

1 - Abnormal unilateral or bilateral signal intensity in striatum and ribbon sign in one gyrus of the cerebral cortex.

2- Ribbon sign in more than 3 cortical gyri (in the absence of lesions in T1-weighted slices and white matter).

For the patients with predominant signal changes, these findings emerge within 10 weeks after the symptoms start and these cases were often associated with neuropsychiatric symptoms. Alien hand syndrome, dystonia, Parkinsonism and ataxia may also be seen (4). In our patient, the cortical ribbon sign seen in the frontal cortex facilitated the diagnosis of sporadic CJD.

\section{References}

1. Shiga Y, Miyazawa K, Sato S, Fukushima R, Shibuya S, Sato Y, Konno H, Dohura K, Mugikura S, Tamura H, Higano S, Takahashi S, Itoyama Y. Diffusionweighted MRI abnormalities as an early diagnostic marker for CreutzfeldtJakob disease. Neurology 2004;63:443-449.

2. Tschampa HJ, Kallenberg K, Urbach H, Meissner B, Nicolay C, Kretzschmar HA, Knauth M, Zerr I. MRI in the diagnosis of sporadic Creutzfeldt-Jakob disease: a study on inter-observer agreement. Brain 2005;128:2026-2033.

3. Young GS, Geschwind MD, Fischbein NJ, Martindale JL, Henry RG, Liu S, Lu Y, Wong S, Liu H, Miller BL, Dillon WP. Diffusion-weighted and fluid-attenuated inversion recovery imaging in Creutzfeldt-Jakob disease: high sensitivity and specificity for diagnosis. AJNR Am J Neuroradiol 2005;26:1551-1562.

4. Yi SH, Park KC, Yoon SS, Kim EJ, Shin WC. Relationship between clinical course and Diffusion-weighted MRI findings in sporadic Creutzfeldt-Jakob Disease. Neurol Sci 2008;29:251-255. 